\title{
An application of extensive reading to English for academic purposes programs at tertiary level for functional academic literacy: A Turkish case-study
}

\section{Bekir Savaş}

\section{OpenEdition}

\section{Journals}

Electronic version

URL: http://journals.openedition.org/asp/254

DOI: $10.4000 /$ asp. 254

ISBN: 978-2-8218-0408-1

ISSN: 2108-6354

Publisher

Groupe d'étude et de recherche en anglais de spécialité

\section{Printed version}

Date of publication: 1 March 2009

Number of pages: $65-84$

ISSN: 1246-8185

\section{Electronic reference}

Bekir Savaş, «An application of extensive reading to English for academic purposes programs at tertiary level for functional academic literacy: A Turkish case-study », ASp [Online], 55 | 2009, Online since 01 March 2012, connection on 02 November 2020. URL : http://journals.openedition.org/asp/ 254 ; DOI : https://doi.org/10.4000/asp.254

This text was automatically generated on 2 November 2020

Tous droits réservés 


\title{
An application of extensive reading to English for academic purposes programs at tertiary level for functional academic literacy: A Turkish case-study
}

\author{
Bekir Savaş
}

\section{Introduction and rationale}

1 Education is becoming more international, multilingual and multicultural. More students are spending more time learning through another language: reading a textbook, a newspaper or a journal in another language; having some or their entire curriculum taught in another language; accessing foreign language material on the Internet; or communicating in a foreign language with native speakers in other parts of the world (Mohan \& van Naerssen 1997: 23). In short, besides their first language (L1), students learn a foreign language (L2) at school in order to read not only for pleasure but also for academic development.

Unlike basic interpersonal communication skills (BICS), a concept developed by Cummins (1979: 225), learning through a foreign language entails well-developed cognitive academic language proficiency (CALP), which takes a foreign learner at least five to seven years to acquire (Cummins 1979: 226). Therefore, non-native students who want to study in American universities often run into difficulties during their undergraduate study even if they attained a particular score in the TOEFL exam. High failure statistics of such students caused authorities to replace the newly-changed TOEFL-CBT with the TOEFL-IBT in 2006 to meet the expectations of programs in English-medium universities (Zavera 2005: 2). This situation points to the fact that English for Academic Purposes (EAP) courses for tertiary education may not meet the 
needs of students or maximize the improvement of CALP in English-speaking countries, let alone in non-English ones. CALP is a requirement in universities with English-only medium teaching. Our research object is native language-medium universities where English is taught as a means of academic development. This does not entail thinking in English or CALP in English but a functional academic literacy (FAL) as a means of improving academic knowledge. This paper, therefore, reports on the implementation of an Extensive Reading (ER) component in the EAP program in Turkey to help university students acquire the required level of FAL in English, firstly for academic development while receiving instruction in their L1, and then for professional development in the longer term.

In a tertiary level EAP teaching program, the primary goal is not to teach a foreign language. It is to improve what EAP learners already know through texts meaningful to them with the help of prior content knowledge in L1 or their second language, which learners use to access the scientific knowledge they are researching. Therefore, the learning of foreign language in tertiary education is a means to an end but not the end itself. Universities are key institutions where students are equipped with the skills required to meet the challenges of global development through information technology. An ER-based EAP program provides students with such tools because, through reading many books, journals and research papers that contain comprehensible input, a number of important changes occur in the learner's academic literacy level (Ellis 1995: 14, Krashen 1988: 273, Nation 2001: 13). The idea behind ER is the fact that L2 learners need a large amount of contact with the foreign language in order to become proficient in it, as in the process of natural L1 development.

In our research, we studied first-year EAP classes held in the Engineering Faculty of Kocaeli University in Turkey. These classes aim to improve students' academic English literacy through L2-L1 translation with intensive reading. We hypothesized that this approach is a repetition of general English teaching in the English Preparatory School (EPS) focusing only on form. The ESP in Kocaeli University which students have to attend before starting their academic study provides only limited exposure to English and a fair amount of passive knowledge leading to the acquisition of limited receptive skills. What tertiary level students need, however, is to gain not only receptive but also productive skills in academic English. That is to say, they need functional academic literacy (FAL), through which they can understand, use and reflect on written texts in order to achieve their goals, to develop their knowledge and potential, and to participate effectively in the global society. The research team believed that FAL could be acquired through a new type of reading instruction, and so, devised an EAP program with extensive reading carried out through computer-assisted, task-based activities. We implemented this program in the Engineering Faculty for a year and looked at its influence on the functional literacy development of students. Research results proved that an ER-based approach is more effective than EAP teaching that is based on intensive reading and translation. In the framework of this study, the researchers formulated the following research questions:

- Can English Preparatory School be a base for EAP classes in the first year of university in terms of FAL development? If so, to what extent?

- Is ER more productive than IR in the development of FAL? If so, why and how? 


\section{Literature review}

\subsection{Theories behind extensive reading}

5 A significant part of learning about a concept in a subject matter involves collecting information, organizing this information in a certain way, interacting with the concept, and communicating and understanding this concept. Language helps us in this process because language and meaning naturally interact with each other (Mohan 1989, cited in Mohan \& van Naerssen 1997: 22). Learning is a life-long process in which we use tools that develop from a culture, such as speech and writing, to mediate our social environment. Children learn language while mediating this social environment. After a time, knowledge of language becomes a means of demonstrating higher-order thinking and cognitive skills (Vygotsky 1978: 57). Linguistic and cognitive development continues through problem solving activities under adult guidance or in collaboration with more capable peers. Bruner wrote:

It is impossible for a human being to perceive reality in any objective manner; we rather 'construct' reality while learning something new by means of using mental strategies on the basis of our previous experiences, our prior knowledge and our social interaction. (Bruner 1983: 60)

According to Anderson's schema theory (Anderson \& Pearson 1984: 82), prior knowledge is essential for the comprehension of new information within a given text or context. Readers' mental stores are divided into two main types: "content schema" and "formal schema". They develop a coherent interpretation of a text by combining these two types of knowledge during reading. Similarly, Sinclair (1990: 16) claimed that "in general people forget the actual language but remember the message". The fact remains, though, that textual memory is important as texts carry references to other texts. It is therefore vital for non-native readers to try to accomplish as much reading as possible in order to internalize both types of schema as well as textual memory in L2.

7 Krashen's Input Theory also emphasizes the importance of prior knowledge in L2 reading. Learners must be able to draw meaning from the information they are trying to access. If the text is comprehensible enough for the speaker, that is to say if there is only a 5\% difference between the reader's reading competence and the knowledge coded in the text, the learner can infer this meaning through context. With successive readings, the learner is repeatedly exposed to new words, expressions, structures, and aspects of discourse. He/she begins to form ideas of the meaning and usage of new features, while extending and deepening their understanding of more familiar ones just as learners acquire much of their first language (Krashen 1988: 278). With each exposure, the learner adds to his or her mental mappings or schemas of these features and how they are used in the target language. (Ellis, 1995:16)

Content and formal schemas facilitate comprehension of the texts not only written in one's own language but in the foreign language whose formal schemas they are familiar with, as well. In other words, linking this content knowledge and reading comprehension strategies in L1 with the formal schemas of L2 positively affects vocabulary learning in L2 in particular, language learning in general. Various and numerous studies have been carried out to define the relationship between L1 and L2 reading such as Linguistic Interdependence Hypothesis (LIH) developed by Cummins (1979: 224), the Linguistic Threshold Hypothesis (LTH) or Short-circuit Hypothesis 
developed by Clarke (1980: 205), and Hacquebord's (1989: 79) transfer hypothesis. According to these theories, the cross-linguistic transfer of reading skills is easier in three cases; first, when students read well in their native language (LIH), secondly, when they reach a particular level in L2 reading (LTH) and lastly, when they continue their reading activities in L1 while learning in L2. Especially LIH has revealed that academic functional literacy in one's own language plays a crucial role in the acquisition of similar linguistic skills in a foreign language too.

Theories of first-language acquisition mean that spoken language that is acquired preschool and written language learned at school are ways of learning and enhancing both linguistic competence and world knowledge. This is a process of intra-lingual transfer realized diachronically. Likewise, hypotheses of inter-lingual transfer of linguistic skills mean that skills acquired in L1 are also influential in the acquisition of similar skills in L2. However, this requires well-developed literacy both in L1 and in L2. According to De Castell (1981: 8) "A person is literate when he has acquired the essential knowledge and skills which enable him to engage in all those activities in which literacy is required for effective functioning in his/her group of community." This means that today's university students need "functional literacy" not only in L1 but also in L2 in order to acquire new knowledge. A reading program that aims to develop such literacy is the most beneficial for first language development and for learning L2, which in turn contributes to learning in general. A tertiary level EAP program should therefore aim to provide students with FAL through ER.

\subsection{What is extensive reading and how is it different from intensive reading?}

10 ER is a language development technique, whether it is applied to L1 or L2. Language learners read numerous comprehensible texts for pleasure, an activity which should be continued over a sustainable period. This is a slow process as in natural language learning and it resembles the "whole-language approach" (Goodman 1967: 128). Both approaches assert that language is a natural phenomenon and that literacy is promoted through natural, purposeful language function. Both approaches use, as their foundation, current knowledge about language development as a constructive, meaning-oriented process in which language is viewed as an authentic and natural real-world experience. Lastly, both approaches perceive language learning as taking place through functional reading and writing situations.

11 The goal of an ER approach is to get students to enjoy reading in the target language. It is an approach that sees reading not merely as a skill or as texts for translation, but as an activity that one chooses to do for a variety of personal, social, or academic reasons (Day \& Bamford 2000: 14). The prime focus of ER is on the meaning of what is being read, in other words on content schemas rather than on the language. On the other hand, in intensive reading, students work with much shorter texts under the guidance of the teacher. The aim of intensive reading is to help students construct detailed meaning from the text; to develop reading skills, such as identifying main ideas and recognizing text signals; and to enhance their knowledge of vocabulary and grammar, namely formal schemas. This type of L2 learning cannot be sustained on a long-term basis. Students must leave school at a particular age and they then have to take on the responsibility for their own learning. Reading for pleasure and learning at school 
through ER encourages students to take on this responsibility. Day and Bamford (1997:

8) listed the following as key characteristics of a successful ER program:

- students read large amounts of printed material;

- they read a variety of materials in terms of topic and genre;

- the material they read is within their level of comprehension; - they choose what they want to read;

- reading is its own reward; - students read for pleasure, information and general understanding;

- they read their selection at a faster rate than when they did intensive reading;

- reading is individual (students read on their own);

- teachers read with their students, thus serving as role models of good readers;

- teachers guide and keep track of student progress.

\subsection{How does extensive reading function?}

12 According to Waring (1997: 11), extensive reading is the only way in which L2 learners can access language at their own comfort level, in other words they read materials that they want to read, at a pace that they feel comfortable with. This allows them to encounter the language enough times to pick up a 'sense' of how the foreign language they are learning fits together and helps to consolidate what they already know. Waring goes on to say that it is impossible for us to teach this 'sense' of language. Every language has its own way of encoding meaning and teachers do not have time, nor is it their job, to teach this. It is the learners' job to acquire that sense for themselves. This depth of knowledge of a foreign language must, and can only, be acquired through constant and substantial exposure to the language through extensive reading. A continuous exposure to a foreign language provides an intertextual transfer of sense or depth of L2 knowledge because, as Sinclair (1990:16) suggests, texts carry references to other texts, which facilitates their comprehension and increases learners' enjoyment. If L2 learners do not acquire that sense, they will inevitably fall back on the strategies they use to make sense of their L1, while reading an L2 text, causing mother-tongue interference. Transference of L1 reading skills and strategies into L2, as described in Cummins' and Clarke's LIH and LTH hypotheses, far from contributing to L2 learning, in fact in this case, may prevent it.

Another reason for ER to be included in any language-teaching program is the psycholinguistic process of learning new words. Nation (2001: 35) describes the process of vocabulary acquisition as occurring in three steps: encountering, establishing and elaborating. "Encountering" is the initial learning. At this point, a lexical or grammatical item may or may not have been perfectly understood or learned on the first encounter and will certainly disappear from memory quickly if not reencountered. "Establishing" means rooting the new item in the long-term memory through repeated encounters. "Elaborating" is noticing different sense relations of words within different texts. L2 learners acquire this sense through task-based ER. Studies of implicit vocabulary acquisition have shown that L2 learning through ER is useful as it is almost certainly similar to native speakers' acquisition of the majority of their vocabulary. (Saragi, Nation \& Meister 1978: 76) 
Studies aiming to show the contribution of ER to vocabulary development in particular and linguistic, academic, and pedagogical development in general, have found out the following:

1. ER not only develops reading skills but also benefits a whole range of other language skills, boosts confidence and motivation and improves learners' overall attitude to L2. Reading in this sense has to be seen holistically, as a crucial part of students' total development. (Powell, 2005: 29)

2. It increases students' exposure to the foreign language, which enhances their general language competence. The quality of exposure to language that learners receive is seen as important to their ability to acquire new forms from the input. There is a "spread of effect from reading competence to other language skills - writing, speaking and control over syntax". (Elley 1991: 404)

3. It facilitates the development of prediction skills. One of the accepted perspectives on the reading process is that it involves the exploitation of background knowledge. Such knowledge is seen as providing a platform for readers to predict the content of a text on the basis of a pre-existing schema. When students read, these schemas are activated and they help the reader to decode and interpret the message behind the printed words. These processes presuppose that readers predict, sample, hypothesize and reorganize their understanding of the message as it unfolds while reading. (Nunan 1991: 65-66)

4. Success in individual reading encourages learner autonomy which leads to "learning success and enhanced motivation" (Dickinson 1995: 168). Mason and Krashen (1997: 93) found that the majority of students who were once reluctant EFL learners become eager readers as a result of comprehensible input with increased exposure to L2 through extensive reading. The overall aim of $\mathrm{L} 2$ teaching is to create autonomous learners.

5. Davis (1995: 335) advocates the inclusion of ER components into EAP teaching, indicating "It should be seen as core and indispensable part of language programs as it accelerates the learning, which is too slow in L2 teaching when compared with the length of the process of natural language development." ER is, therefore, a process of naturalization of foreign language learning, teaching learners how to read academic texts to learn L2 in a natural way.

15 To sum up, language is acquired through comprehensible input that is just a little above one's current language level. However, besides comprehension, production also has a direct role to play in the acquisition of a language. Swain's Output Hypothesis (1995: 129), explains the above-mentioned spread of effect of ER from reading competence to other language skills, i.e., writing, speaking and control over syntax, namely a sense of the textual information in L2. This influence increases when extensive reading is integrated with teaching of productive skills in EAP classes. Swain holds that there are three functions of "output". First learners 'notice' gaps in their linguistic knowledge while producing language. Through noticing this gap in their knowledge, they may reanalyze their knowledge of the language system. On the basis of this analysis they are then able to generate and test alternative ways of saying what they want to say, which is the "hypothesis testing" function. Thirdly, output has a "reflective" or "metalinguistic" function, i.e., in trying to solve a problem in their output, learners may consciously reflect upon the nature of the language system. Such reflection can aid acquisition as it makes the process of noticing and hypothesis testing more explicit to the learner. An EAP program with task-based ER, therefore, helps learners to improve their productive skill as well, while they are learning English through meaningful contexts and settings. 


\section{The study}

\subsection{Method}

16

Our research was conducted within the EAP program in the Engineering faculty of Kocaeli University in Turkey. To test and validate our hypothesis, a case-study was set up; we put our project into practice in the EAP program in the first year of the Engineering Faculty. Students of Electrical Engineering formed the experimental group in ER while those of the Electronic Engineering Department were the control group who continued to learn academic English through intensive reading and translationbased EAP classes. Both groups sat exams that were the same in form but field-specific in content. These exams were prepared by the testing office for all EAP classes in the faculty and were held monthly. They aimed to measure the reading comprehension skills, grammar and vocabulary knowledge of EAP students. At the end of the year, we compared the results of both groups and found notable differences between the performances of the two groups in all testing categories.

\subsection{Participants}

Sixty first-year students from the Electrical Engineering Department in Kocaeli University participated in the study as the experimental group and fifty-two first-year students from the Electronic Engineering Department as the control group. Sixty-eight percent of the students in the control group, and sixty-five per cent of the experimental group had attended English Preparatory School for a year before they started the EAP course. The rest had passed the proficiency exam and started their first year directly. Both groups had basic Engineering classes in L1 in their first year, regardless of their department. This meant that they learned almost the same content knowledge while attending their EAP classes.

\subsection{Procedures}

Generally speaking, in the ER, task-based EAP class, students were expected to work collaboratively towards the achievement of a final product, writing a report on their topic and its presentation in the class. Pair and group work as well as interaction with ELT teachers and content-area lecturers were used effectively to promote communicative language learning and develop students' social and professional experience together with their FAL. Steps of the experiment were as follows:

- Students were initially briefed about the goals of the program and the principles of extensive reading. The methodology was also explained to them so that they could benefit from the program as much as possible.

- An initial placement test was held to determine who would work with whom in task groups. Those who were good at speaking or writing were selected so that they would be appointed as the speaker or writer of the groups in order to provide peer scaffolding.

- Initial results of the placement test showed that students considered word-for-word decoding to be the only way to read. Therefore, they were shown, as part of the orientation, how to read texts or hypertexts critically and how to purposefully prepare projects for 
presentation in EAP classes. Critical reading was the functional skill that the EAP learners most needed.

- In the experimental class, 10 topics per term from those that were to be taught in contentarea classes in their L1 were determined with the participation of students.

- With the aim of providing peer teaching through collaboration, ten groups were formed out of the 60 students according to their competence levels and strengths as determined in the placement test. The groups were then instructed to choose their topics.

- Each student was told to find at least two files of research papers or other type of texts, such as popular science magazines, related to their group's topic from various sources at least two weeks before their presentation. These were mainly taken from the Internet or found in the library. Students were not only taught how to cope with this information effectively but also how to organize it for their own use.

- Thus each group compiled its own ER materials of about 100-120 pages which made up a presentation file that was sent on-line to members of other groups to be read before the presentations. Students were given the flexibility to choose their texts according to their own level of comprehension and they could read them wherever and whenever they wanted. - While preparing for its presentation, each group held a meeting to decide what to talk about, for how long and in what way. Groups wrote a report referring to general facts, procedures and applications in electrical engineering. They also prepared reading comprehension questions for the listeners who had also read that week's file on-line before coming to class. Listener groups also prepared questions about points on which they needed clarification.

- Audio-visual aids were used during presentations, facilitating comprehension and the perception of scientific processes through diagrams, charts, pictures or videos.

- The teacher acted as a role model for students by being an active member of the classroom reading community and by demonstrating what it means to be a reader and the rewards of being a reader. He advised the students about rewriting, editing, and correcting presentation papers. The teacher also had a fair amount of content knowledge in electrical engineering from previous training.

Generally speaking, these activities involved using secondary classroom skills such as taking clear and brief notes and asking and understanding questions and they also involved using cognitive and meta-cognitive strategies as well as entailing the development of higher-order thinking and learning skills. Students engaged in activities that involved the development of language learning skills, such as reading from different sources, writing summaries of the information they had collected, reporting on their experiences to the class and listening to the reports presented by their classmates. Secondly, students produced their own corpora, providing them with the opportunity to be creative, show critical awareness and communicate with others. Students also had a greater degree of control and certainty of the suitability of the texts for their aims and field of study when compared with the control group.

In order to assess academic language proficiency, monthly multiple-choice exams were set for both groups (six exams in total with 50 questions in each, see Appendix 2). The tests were in the form of fill-in-the blank questions which measured reading comprehension of scientific texts and knowledge of word meaning and sentence structure. The organization of the exam papers was the same in both the ER and IRbased EAP programs but the content was field-specific. The exam format included reading comprehension passages, cloze test questions, sentence or paragraph 
completion questions, reflecting the reader's grasp and correct implementation of the resources necessary to construct meaning. According to Donin, Graves and Goyette (2004: 58), these resources assist readers in utilizing lexis and syntax, retrieving meaning from their mental lexicon, making inferences, and employing schemas. The correct implementation of these resources can help readers in the successful comprehension of the text.

21 A supplementary source of data was also included in the experimental design; we made use of statistical data from the UDS test which is an official foreign language test held bi-annually by the Institute of Higher Education. Approximately 50,000 candidates for post-graduate study sit this exam twice a year. Results of this exam are a first-hand indicator of the effectiveness of intensive reading and academic translation based EAP programs, as practiced in Turkish universities since 1995 under the name "Reading Comprehension through Translation". The test includes 80 multiple-choice questions, measuring mostly reading comprehension of scientific passages unlike the TOEFL test, which also measures listening and writing skills. The exam is carried out in French, German or English and candidates of post-graduate programs have to obtain 50 points out of 100 to start an MA course, and 65 points for a $\mathrm{PhD}$ position. It is a challenging exam as it requires knowledge of low frequency Academic Word List words and reading comprehension skills together with a great deal of field-specific content knowledge. Therefore, according to results of the latest UDS, those who did the test in English understand only half of what they read in academic English (see table 2).

\section{Analysis of the data}

\subsection{Evaluation of the results of the monthly exams}

As a result of evaluation of monthly exams, we found that the success rate of the control group was $52.38 \%$ for the students who had attended English Preparatory School (EPS), and $80.85 \%$ for those who did not need to. However, in the ER-based EAP program, it was $61.71 \%$ for those who had attended prep class and $88.20 \%$ for those who did not need to (see Table 1). In answer to our first research question "Can English Preparatory School be a base for EAP classes in the first year in terms of FAL development? If so, to what extent?", the figures in the first column of Table 1 account for the fact that basic interpersonal communicative skills (BICS), which are acquired in EPS help students learn academic English regardless of the type of reading instruction during the first-year EAP classes. However, the degree of this contribution is limited. Due to particular conditions which will be discussed later, only half of the control group managed to achieve the pass mark of $50 \%$. Attending EAP training with taskbased ER, however helped an additional $9.33 \%$ students to pass the EAP class. This difference corresponds to approximately $20 \%$ of students who failed the EAP class.

The figures in Table 1 also provide insight into the second research question: "Is ER more productive than IR in the development of FAL?. If so, why?" All figures confirm that the ER-based EAP program was more successful than the intensive reading, translation-based EAP program in developing students' academic literacy. 
Table 1. Success rates*

\begin{tabular}{|l|l|l|l|l|}
\hline & $\begin{array}{l}\text { Students with EPS } \\
\text { training }\end{array}$ & $\begin{array}{l}\text { Students not needing } \\
\text { EPS training }\end{array}$ & $\begin{array}{l}\text { Difference with/ } \\
\text { without ESP }\end{array}$ & $\begin{array}{l}\text { Average } \\
\text { success rates }\end{array}$ \\
\hline IR Class & $52.38 \%$ & $80.85 \%$ & $28.47 \%$ & $66.6 \%$ \\
\hline ER Class & $61.71 \%$ & $88.20 \%$ & $26.49 \%$ & $74.9 \%$ \\
\hline $\begin{array}{l}\text { Success } \\
\text { rate } \\
\text { difference }\end{array}$ & $9.33 \%$ & $7.35 \%$ & & $8.3 \%$ \\
\hline
\end{tabular}

* Percentages of those who got 50 points or above out of 100; EPS: English Preparatory School

Perhaps the most striking result, in relation to the second research question is the fact that those who did not need to attend EPS and started EAP training directly were much more successful than those who had to attend EPS first to learn BICS, regardless of the type of reading instruction in the EAP program. The answer to the question of how ER or IR achieves this lies in the long-term process of BICS acquisition. This situation is explained by Krashen's acquisition-learning hypothesis. According to Krashen (1981: 37) there are two independent systems of second language performance: "the acquired system" and "the learned system". The former is the product of a subconscious process very similar to the process children undergo when they acquire their first language. It requires meaningful interaction in the target language - natural communication - in which speakers concentrate not on the form of their utterances, but on the communicative act. On the other hand, the "learned system" or "learning" is the product of formal instruction and comprises a conscious process which results in conscious knowledge about the language, for example knowledge of grammar rules as learned in EPS. According to Krashen, "learning" is less important than "acquisition". IR provides mostly "learning" about the language system, while ER supplies learners with an "acquisition" of the academic language.

25 A link was also apparent between these results and the theories put forward by Vygotsky, Bruner and Anderson on the natural language learning process, together with theories of cross-linguistic transfer of reading skills by Cummins, Clarke and Hacquebord. Figures in the first two columns of Table 1 confirm Bruner's constructivist learning theory and Cummins' (LIH), while those in the second column validate Clarke's (LTH). For instance, difference with/without ESP training in IR class is $28.47 \%$ while it is $26.49 \%$ in ER class because the former followed the same approach to L2 teaching as the one students not needing ESP training attended in their previous training. Similarly, the huge success difference between students who needed or did not need ESP training, which is $27.48 \%$ confirms the influence of L2 competence in EAP class. In short, the more previous content and L1 and or L2 knowledge or skills a student has, the more he/ she is able to learn L2 knowledge and skills.

A more detailed comparison of the results was then carried out, revealing differences between the two groups in terms of utilizing their knowledge of lexis, syntax and reading comprehension skills. In the exams, there were multiple-choice, fill-in-the blanks questions that measured knowledge of word meaning, grammar, syntax and 
coherence together with reading comprehension questions (see figure 1). Fill-in-the blanks and sentence completion questions require knowledge of word meaning and grammatical structures but reading comprehension questions need knowledge of all aspects, in other words knowledge of lexis and syntax, together with knowledge of textual organization at sentence and paragraph levels. This accounts for the fact that the biggest difference between IR and ER (18.61\%) is in terms of reading comprehension.

Figure 1. Detailed comparison of IR and ER programs

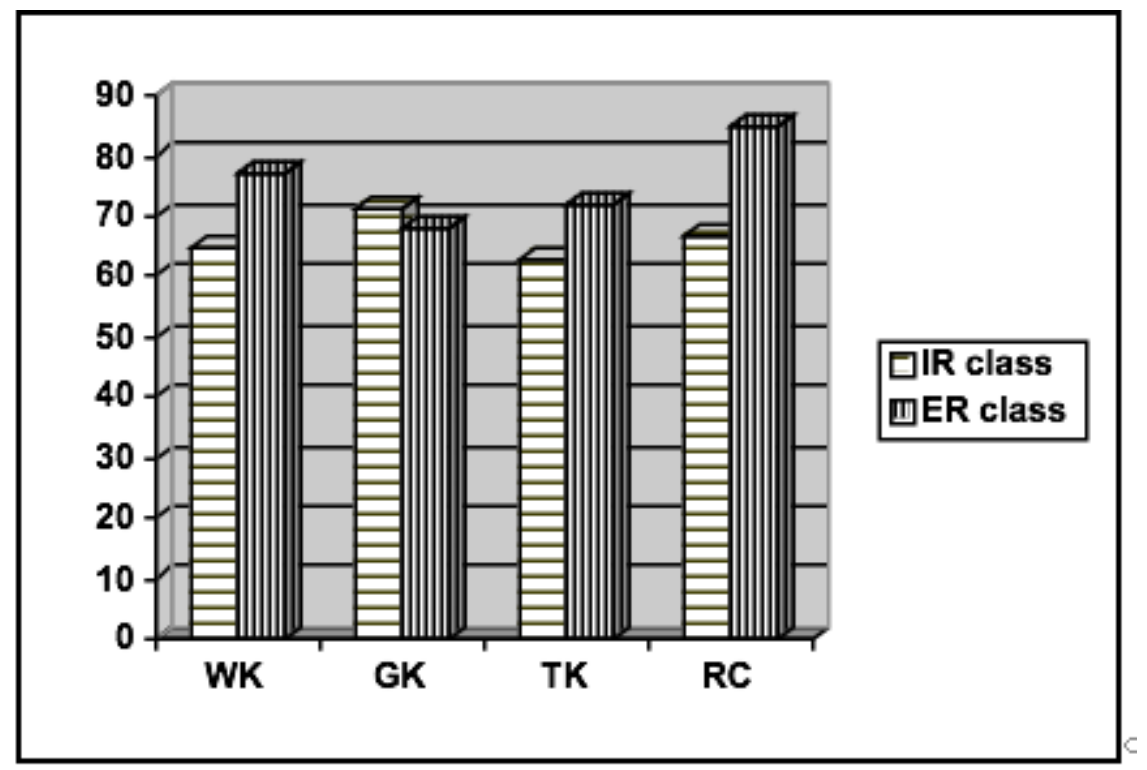

WK: word knowledge; GK: grammar knowledge; TK: textual knowledge; RC: reading comprehension

EAP programs should teach enough vocabulary to their students to meet their perceived needs (Seal 1991: 302). Nation (2001: 33) holds that words cannot be regarded as isolated units of language; they should be incorporated into many interlocking systems and levels of language. In this sense, ER in EAP classes is a very suitable way of improving academic word knowledge and then the reading comprehension skills of students as indicated by the data in figure 1 . The biggest success difference between the experimental and control groups was in reading comprehension levels (18.61\%), which accounts for the fact that the amount of word knowledge acquired incidentally or implicitly through ER is higher than that learned intentionally or explicitly as in IR. Explicit grammatical knowledge is the only criterion in which IR students seem to do better than ER students. This may originate from their extensive focus on grammar and use of meta-language during explicit grammar teaching in EAP classes.

\subsection{Evaluation of the statistics of the UDS test}

This evaluation was included to test the findings which clearly demonstrated that ER is more productive then IR in improving FAL in answer to the second research question. Although these statistics were from a secondary source of information, we felt they would provide a more complete external validity than the ones obtained from our control group. 
Analysis of the latest results of the UDS test shows that candidates planning to enter post-graduate study in Turkish universities do not understand half of what they read in L2 (see table 2). This means that EAP training with intensive reading and translation during their undergraduate study have not made a big enough contribution to their academic literacy. It is clear that this situation will directly affect their academic success in their future programs if they are able to enrol. In other words, IR is less beneficial than ER in EAP programs for FAL development at university because it does not provide students with enough exposure to academic texts and enough practice with them to strengthen their 'sense' of academic texts.

Table 2. Academic L2 literacy levels of candidates of post-graduate study*

\begin{tabular}{|l|l|l|l|}
\hline Fields & Mean & Std. dev. & Candidate numbers \\
\hline Medicine & 58.42 & 21.73 & 8,763 \\
\hline Science & 53.64 & 19.82 & 23,663 \\
\hline Social sciences & 49.75 & 18.82 & 22,066 \\
\hline Foreign Languages & & & \\
\hline German & 57.00 & 22.01 & 736 \\
\hline French & 59.50 & 20.03 & 430 \\
\hline English & 49.75 & 18.31 & 53,336 \\
\hline
\end{tabular}

* Source <www.osym.gov.tr>

\section{Discussion}

\subsection{Results of the experiment and previous studies}

The English Preparatory School in Kocaeli University, where $66.5 \%$ of new students started learning English for the first time before they start the undergraduate program, is important in the development of students' academic literacy. Although students can only graduate from this school if they get 70 points in the exams, $48 \%$ of them failed EAP class though the pass mark is 50 in the first year. This situation may be explained by the Constructivist learning theory focusing on the importance of prior knowledge and by inter-lingual transfer hypotheses emphasizing the importance of L1 and L2 reading skills. The EPS curriculum in Kocaeli University does not include any learning through academic texts. EAP students therefore have no prior knowledge of academic language that they can transfer into their new learning setting, having only knowledge of general English or BICS. (Karabag \& Savas 2007)

31 The huge difference between proficiency levels of those who enrolled in the EAP program after attending EPS and those who did not have to attend EPS arises mostly from the length of time during which they had been exposed to the foreign language. 
Cummins holds that BICS are not sufficient for academic success in English-only instruction. Students studying in an L2 need to have cognitive academic language proficiency (CALP) as well but acquisition of CALP in L2 takes five to seven years (Cummins 1979: 226). Our students do not receive instruction in English, which requires CALP in L2. They learn English for academic and professional development. However, one year is not sufficient to achieve this and more time and practice are necessary, as shown by the ER results.

The results we obtained from this research together with those gathered in previous research account for the fact that ER in tertiary level EAP is more useful than intensive reading. Since the students in our research made use of the content-area knowledge they learned in other classes held in L1, they found ER more meaningful, easier and more interesting, as suggested by Cummins' LIH. Our students' content knowledge helped them as it also provided them with familiarity with the jargon of electrical engineering most of which is composed of terms borrowed from English. This facilitates comprehension of the content and thus, acquisition of FAL in the ER, task-based EAP program (see Appendix 1). This is the same for speakers of European languages which include Greco-Latin loan words. Table 2 also confirms the facilitating influence of loan words in reading comprehension. Among candidate students sitting the UDS language test for an MA or PhD degree, the most successful ones are those who study medicine as medical terms in Turkish are almost always Greco-Latin loan words.

Another factor that made the ER-based EAP teaching more productive was the integration of the four skills. In light of Swain's output hypothesis (1995: 129), we integrated extensive reading with writing and speaking activities to enhance the productive skills of students. Results of research carried out by Golkar and Yamini (2007: 98) indicated that the learners' passive vocabulary was larger than their active vocabulary and they could use only $58 \%$ of their passive vocabulary productively. This difference was much higher in academic passive and active vocabulary. Therefore, presentation groups prepared their report collaboratively, making use of peer tutoring and brain-storming which provided interactive communication opportunities during team work. Students gave a briefing to the teacher before their presentations, therefore practicing academic language. The listener groups also benefited from this interactive communication as they were expected to prepare questions before the class and ask their questions during or after the presentation for clarification. Therefore, this productive approach enhanced FAL for students in the experimental group.

\subsection{Reflections on the rationale of extensive reading in EAP}

Although the above-mentioned results, together with the findings of other research, indicate that ER in tertiary level EAP programs is more useful than intensive reading, questions remain about the validity of independent ER. For instance, it is asserted that the reading materials chosen by the readers themselves may be too simple. Davis (1995: 329) refuted this assertion in this way: "The watchwords are quantity and variety, rather than quality, so that books are selected for their attractiveness and relevance to the pupils' lives, rather than for literary merit." If reading materials are in the students' fields of interest, comprehension is made easier because the students have knowledge of the subject matter. Day and Bamford (2000:16) state that in cases where the teacher makes the selection, students' interests should be considered of utmost importance. In our case, however, academic texts were not chosen by the teacher. The 
students read the texts in order to learn particular scientific facts that they are already familiar with and about which they have prior knowledge and they are therefore better able to choose their own materials than the teacher, generally an EFL specialist. The simplicity of the texts does not matter, what matters is the flexibility of material according to needs and interests of the students.

Another possible criticism of ER programs concerns the role and function of the teacher. At first sight in an ER class, the teacher does not appear to be teaching. However, the role of the teacher is directly related to the approach to language teaching. In an IR approach, which is a teacher-centred teaching, this includes explaining the meaning of hard-to-understand sentences; asking students to translate certain passages or answer comprehension questions; and giving further explanations of grammar, vocabulary or content of the passage while students simply listen attentively in order to understand. On the other hand, in an ER approach which is a student-centred, communicative approach the teacher sets up the course so that students can each have books suited to their level and interests, plans class activities that motivate students to read, uses various techniques to check that students are in fact reading, oversees record-keeping of books they have read, advises individual students who are falling behind and gives individual feedback to students on book reports and other written work. The overall aim of L2 teaching is to create autonomous learners with intrinsic motivation, not learners who always need the extrinsic motivation of a teacher or classroom teaching.

This last point is particularly important, given that class. In an ideal situation, students have to work on their own and improve their knowledge if they want to learn how to use it. Therefore, universities should teach a FAL in L1 and L2 to enable autonomous learning through information technology. The question of vocabulary particularly reflects the importance of learning autonomy: FAL is more than just learning words. If it were so, those who had memorized the most widely used 2,000 words in English from a particular course book would be able to communicate easily. There are also shades of meaning, nuances and pronunciation to learn, as well as each word's collocations and colligations. It takes native speakers 5-6 years in which they are exposed to such features of language before they finally feel comfortable enough to use them correctly. No L2 learner has the time and suitable conditions to methodically go through and learn all of this knowledge as no course book, or course, can possibly hope to cover even a small proportion of them. ER, which encourages autonomous learning, therefore, seems to be the best means of accelerating the process of vocabulary development in $\mathrm{L} 2$ learning.

The above reflections on ER vs IR do not mean that the latter does not have its place in L2 teaching. What is not useful, however, is its repetition after its application in the English Preparatory School when it should be replaced with ER in order to meet the new needs of the students. Carrell and Carson (1997: 49) claim that these two approaches to teaching reading - intensive and extensive reading - should not be seen as opposing methods, since both serve different but complementary purposes. For this reason, instead of repeating the same method used in English Preparatory School in EAP classes, it would be more effective to use ER as a way to expose our students to a variety academic texts, facilitating reading comprehension and acquisition of FAL through intertextual and inter-lingual transfer. 


\section{Implications}

Overall, there is little doubt in the ELT literature that ER contributes to learners' L2 reading skills, when reading for pleasure during secondary level education. Our findings suggest that ER in EAP programs at tertiary education has beneficial effects on the students' 'reading for learning', enabling them to learn skills that develop their FAL. As a minimum, students may be required to read some academic texts in English, though they may write about or discuss them in their L1 (Crandall, 1998: 3). The influence of ER is most intensively felt in reading comprehension skills, which may also affect their academic success. Indeed, in some cases, the effects of ER appear to be substantially greater when EAP learners start the program after a long period of EFL learning. Therefore, general English teaching in EPS should at least be supported with reading academic texts in reading classes so that students acquire a familiarity with the basic academic terminology before starting the first-year EAP program. In fact, students can also begin learning English grammar with the help of scientific texts at a suitable level of difficulty.

To sum up the results of our research suggest the following:

ER should be implemented in tertiary level EAP programs especially if:

- there are no specially printed materials for EAP as in graded readers used in ER for pleasure;

- exposure to foreign language is limited, such as in non-English speaking settings.

ER is useful in EAP because:

- it provides students with the opportunity to transform passive vocabulary learned during sustained reading at home into active vocabulary during classroom discussion;

- knowledge. This is useful even if it is in their mother tongue as there is a cross-linguistic transfer of reading skills and content-knowledge.

\section{ER is influential in EAP when:}

- it is assisted by computer use to search for information and compile it;

- flexible materials chosen by students themselves are used;

- it is complemented by writing and speaking activities;

- it is applied after a long period of L1 and L2 learning;

- learners continue reading academic texts in their mother tongue as well;

- learners' academic L1 includes terms borrowed from L2 academic language.

\section{Limitations and Recommendation for further studies}

Functional academic literacy includes productive skills as well. Many researchers point out the enhancement in speaking and writing skills of students who do extensive reading. However, for administrative reasons, it was not possible to measure the development in the productive skills of the students in either the experimental or the control group. The extent of contribution that ER, or IR, in EAP training make to writing and speaking skills of undergraduate students, therefore, needs to be explored. As a second study, a long-term protocol investigating our approach to EAP teaching with extensive reading could be introduced in the following years, checking whether it 
contributes to the academic and professional development of undergraduate and postgraduate students.

I would like to thank my colleague Mr. Nuri Kongur, the ELT teacher who carried on the project in his class, which is the most challenging part of the research.

\section{BIBLIOGRAPHY}

Anderson, R. C. and P. D. Pearson. 1984. "A schema-theoretic view of basic processes in reading comprehension". in Carrell, P. L., J. Devine and D. E. Eskey (eds). 1988. Interactive Approaches to Second Language Reading. New York: Cambridge University Press, 37-55.

Bruner, J.S. 1983. Child's Talk: Learning to use language. Oxford: Oxford University Press.

Carrell, P.L. and J. G. Carson. 1997. "Extensive and intensive reading in an EAP setting”. English for Specific Purposes 16/1, 47-60.

Clarke, M. 1980. "The short circuit hypothesis of ESL reading or when language competence interferes with reading performance". Modern Language Journal 64/2, 203-209.

Crandall, J. A. 1998. “Teacher education for integrating language and content instruction”. Forum $36 / 1,2-9$.

Cummins, J. 1979. "Linguistic interdependence and the educational development of bilingual children". Review of Educational Research 49, 222-251.

Cummins, J. 1981. “Age on arrival and immigrant second language learning in Canada. A reassessment”. Applied Linguistics 2, 132-149.

Davis, C. 1995. “Extensive reading: An expensive extravagance?” ELT Journal 49/4, 329-336.

Day, R. R. and J. Bamford. 1997. "Extensive reading: What is it? Why bother?" The Language Teacher 21/5, 6-12.

Day, R. R. and J. Bamford. 2000. "Reaching reluctant readers." English Teaching Forum. Online 38/3 $<$ http://exchanges.state.gov/forum/vols/vol38/no3/p12.htm>.

De Castell, S. 1981. “On defining literacy”. In S. De Castell, A. Luke and K. Egan (eds.). Literacy, Society and Schooling. Cambridge: Cambridge University Press, 7-18.

Dickinson, L. 1995. “Autonomy and motivation: A literature review. System 23/2, 165-174.

Donin, J., B. Graves and E. Goyette. 2004. “Second language text comprehension: Processing within a multilayered system”. The Canadian Modern Language Review 61/1, 53-76.

Elley, W. B. (1991). “Acquiring literacy in a second language: The effect of book-based programs." Language Learning. 41/3: 375-411. in Bell, T. (1998)“Extensive reading: Why? And How? "The Internet TESL Journal, Vol. IV, No. 12, December 1998 http://itelj.org/

Ellis, N. 1995. "Vocabulary acquisition: Psychological perspectives and pedagogical implications". The Language Teacher 19/2,12-16. 
Golkar, M. and M. Yamini. 2007. “Vocabulary, proficiency and reading comprehension”. The Reading Matrix 7/3, 88-111.

Goodman, K. 1967. "Reading: A psycholinguistic guessing game". Journal of the Reading Specialist 6, 126-135.

Hacquebord, H. 1989. Text Comprehension of Turkish and Dutch Students in Secondary Education. Dordrecht, the Netherlands: Foris.

Karabag, I. \& B. Savas. 2007. “An analysis of foreign language teaching programs designed for tertiary education with applied linguistics norms". Paper presented at the meeting of Seventh International Language, Stylistics and Literature Conference, Selcuk University, Konya, Turkey. $<$ www.selcuk.edu.tr>.

Krashen, S. D. (1981). Second Language Acquisition and Second Language Learning. Oxford: Pergamon Press.

Krashen, S. D. (1988). "Do we learn to read by reading? The relationship between free reading and reading ability". In Tannen D. (ed.). Linguistics in Context: Connecting Observation and Understanding. Norwood, NJ: Ablex, 269-298.

Mason, B. and S. D. Krashen. 1997. "Extensive reading in English as a foreign language". System 25/1, 91-102.

Mohan, B. and M. van Naerssen. 1997. "Learning through language". Forum 35/4, 22-29.

Nation, P. (1997). “The language learning benefits of extensive reading”. The Language Teacher 21/5, 13-16.

Nunan, D. 1991. Language Teaching Methodology: A textbook for teachers. London: Prentice Hall.

Powell, S. 2005. "Extensive reading and its role in Japanese high schools". The Reading Matrix 5/2, 28-42.

Saragi, T., P. Nation and G. Meister. 1978. "Vocabulary learning and reading". System 6, 72-78.

Seal, B. 1991. "Vocabulary learning and teaching". In Celce-Murcia (ed.) Teaching English as a Second or Foreign Language. Boston: Newbury House, 296-311.

Sinclair, J. M. 1990. "Trust the text", in Coulthard, M. (ed) .1994. Advances in Written Text Analysis. London: Routledge.

Swain, M. 1995. "Three functions of output in second language learning”. In Cook G. and B. Seidlhofer (eds.). Principle and Practice in Applied Linguistics: Studies in honour of H.G. Widdowson. Oxford: Oxford University Press, 125-144.

Vygotsky, L. 1978. "Problems of method". In Mind in Society. (Trans. M. Cole). Cambridge, MA: Harvard University Press, 52-75.

Waring, R. 1997. “Graded and extensive reading-questions and answers". The Language Teacher 21/5, 9-12.

Zavera, A. 2005. "What is new in the new TOEFL-iBT 2006 Test Format?". Electronic Journal of Foreign Language Teaching 2/2, 45-57. 


\section{APPENDIXES}

\section{Appendix1}

The frequency of loan words in a given electrical engineering class

(A definition of the content of ELK332 class. 30 of 64 words are loan words)

\begin{tabular}{|l|l|l|}
\hline ELK332 & $\begin{array}{l}\text { Senkron makinaların yapılışları, uyarma alanları ve bunların Fourier analizi, } \\
\text { çıkı kutuplu makinalarda iki eksen teorisi, reaktansları, senkron generatör ve } \\
\text { Elektrik } \\
\text { Makinaları } \\
\text { II }\end{array}$ & $\begin{array}{l}\text { motorlarda endüvi reaksiyonu, eşdeğer devreleri fazör diyagramları, boşta ve } \\
\text { yükteki karakteristikleri, kısa devre oranı, kısa devre akımı, senkronizasyon, } \\
\text { senkron motorlara yol verme, aktif, reaktif güç ayarı, döndürme momenti, DC } \\
\text { makinalarının yapilışları, eşdeğer devre, temel denklemler, uyarma şekilleri, } \\
\text { moment ifadeleri, endüvi reaksiyonu, komütasyon, generatör, motor } \\
\text { karakteristikleri, hız ayarı, yol verme. }\end{array}$ \\
\hline
\end{tabular}

Appendix 2 Examples of questions in the monthly exams

a) Word knowledge questions (Fill in the blanks)

The point-and-click actions of the computer mouse have made it an ---- popular alternative to keyboard and text-based commands.

A) increasingly B) assertively C) effortlessly D) exactly E) objectively

b) Grammar knowledge questions (Fill in the blanks)

This is not a new theory; quite a lot of scientists ---- on it for several decades.

A) would have worked B) had worked C) have been working D) would work E) have to work

c) Textual knowledge questions (Find the odd sentence out)

I) Apart from hydroelectricity, there are several other non-depletable energy sources in use such as wind turbines and solar heating. (II) However, it is only in relatively few circumstances that any of them prove to be economic. (Ill) In fact, the developing countries account for one-fourth of the world's production and one-fifth of the world's consumption of commercial energy. (IV) Even where they appear to be operating as ordinary commercial ventures, they are usually heavily subsidized. (V) So, at present, oil, natural gas and coal are still the major suppliers of energy in the world

A) I B) II C) III D) IV E) V

\section{d) Reading comprehension questions}

Long after the discovery of electricity, man found that he could use the great power to produce it. At first, he used natural waterfalls. Later, man began to build dams to generate hydroelectric power. Dams are immense structures which hold back the water of a river and form a lake behind. The water is let through under control and allowed to fall through pipes to the turbines below. The rushing water drives the turbines, and as they revolve, they spin electromagnets; these magnets generate electricity.

According to the passage, dams ----.

A) are primarily used to form lakes B) can be used to prevent flooding C) date back to very early times D) were in use well before electricity was discovered E) are important for the hydroelectric power 


\section{ABSTRACTS}

This paper discusses the need for an extensive reading component in English for Academic Purposes programs at the tertiary level as a way of improving students' academic literacy. It presents research results of a project conducted to determine the influence of extensive reading classes on the development of functional academic literacy. The research was carried out within the framework of the inter-lingual transfer hypotheses of Cummins (1981), Clarke (1980), and Hacquebord (1989) together with the theories of first- and second-language learning. Efficiency of extensive reading was evaluated by comparison of academic literacy development of the experimental group who learned academic English through extensive reading with tasks and the control group who learned academic English through intensive reading and translation. Findings indicate that extensive reading is more productive than intensive reading as the former focuses on meaning while the latter focuses mostly on language.

Cette étude porte sur les besoins d'une composante de lecture extensive de l'anglais dans des programmes de niveau universitaire comme moyen d'améliorer la compétence en lecture en L2 des étudiants. Elle présente les résultats d'une recherche menée dans le cadre d'un projet destiné à déterminer l'influence d'un encadrement de la lecture extensive sur le développement de l'apprentissage académique fonctionnel. Cette recherche a été conduite dans le cadre des hypothèses de Cummins (1981), de Clarke (1980) et de Hacquebord (1989) sur le transfert interlinguistique, hypothèses combinées aux théories de l'apprentissage de la première et de la seconde langues L'efficacité de la lecture extensive a été évaluée en comparant le développement du groupe expérimental ayant appris l'anglais à visée universitaire par la lecture extensive et les tâches et celui du groupe de contrôle ayant appris l'anglais universitaire à travers la lecture intensive et la traduction. Les résultats semblent indiquer que la lecture extensive se révèle plus productive que la lecture intensive.

\section{INDEX}

Mots-clés: anglais universitaire, approche par les tâches, instruction universitaire fonctionnelle, lecture extensive, lecture intensive, transfert interlinguistique

Keywords: EAP, English for Academic Purposes, extensive reading, functional academic literacy, intensive reading, inter-lingual transfer, task-based language learning

\section{AUTHOR}

\section{BEKIR SAVAS}

Bekir Savaş has worked as an English for Academic Purposes (EAP) lecturer at the Engineering Faculty of Kocaeli University in Turkey since 1984. After he obtained a PhD in linguistics in 1998, he established the English Language and Literature Department at Kocaeli University. His research interest is in EAP. bsavas@kocaeli.edu.tr 